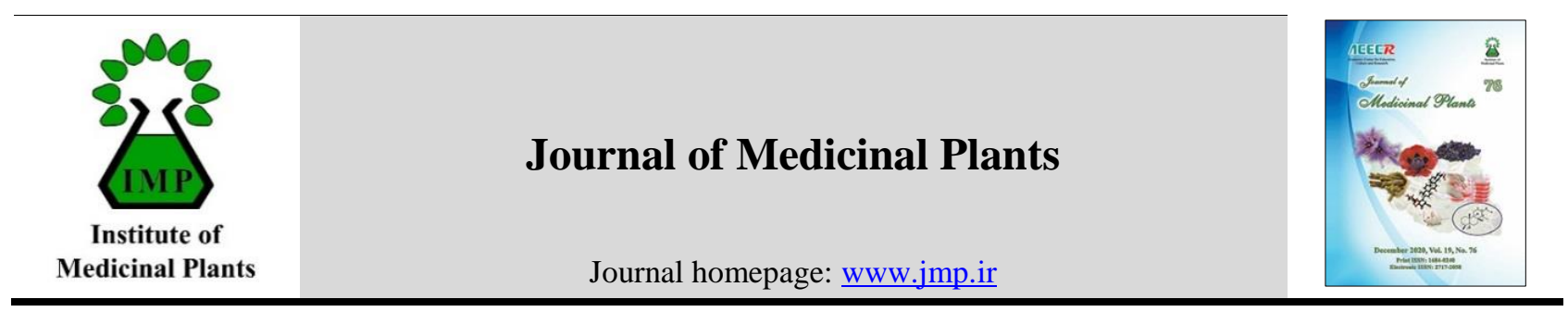

Research Article

\title{
Screening of Apiaceae fruits discovered natural resources with considerable biological potential
}

Zahra Tofighi $^{1,2}$, Mostafa Pirali Hamedani ${ }^{2}$, Saeed Tavakoli ${ }^{3}$, Mir Javad Tabatabaei ${ }^{2}$, Marzieh Rabei $^{2}$, Shamim Mohtadi ${ }^{4}$, Farnoosh Mirghaffari ${ }^{2}$, Maryam Afshani ${ }^{2}$, Farhad Kahrizi ${ }^{2}$, Behruz Khodabandeloo $^{2}$, Saeede Jafari-Nodooshan ${ }^{5}$, Mahdieh Shirzad ${ }^{5}$, Elahe Motevaseli ${ }^{5}$, Saied Goodarzi ${ }^{1}$ **

${ }^{I}$ Medicinal Plants Research Center, Faculty of Pharmacy, Tehran University of Medical Sciences, Tehran, Iran

${ }^{2}$ Department of Pharmacognosy, Faculty of Pharmacy, Tehran University of Medical Sciences, Tehran, Iran

${ }^{3}$ Medicinal Plants Research Center, Institute of Medicinal Plants, ACECR, Karaj, Iran

${ }^{4}$ International Campus, ICTUMS, Tehran University of Medical Sciences, Tehran, Iran

${ }^{5}$ Department of Molecular Medicine, School of Advanced Technologies in Medicine, Tehran University of Medical Sciences, Tehran, Iran

\begin{tabular}{|c|c|}
\hline ARTICLE INFO & ABSTRACT \\
\hline $\begin{array}{l}\text { Keywords: } \\
\text { Umbelliferae } \\
\text { Fruits } \\
\text { Cytotoxic } \\
\text { Reducing power } \\
\text { Phenol content }\end{array}$ & $\begin{array}{l}\text { Background: Apiaceae fruits as common spices used for prevention of many chronic } \\
\text { diseases including cancer. Objective: The present study compared the biological } \\
\text { effects of different fruits from various Apiaceae tribes to compare and find the fraction } \\
\text { source(s) with potential characteristics for further investigation including cancer } \\
\text { prevention. Methods: Fruits of Apium graveolens L. (celery), Bunium persicum } \\
\text { (Boiss.) B.Fedtsch. (black cumin), Petroselinum crispum (Mill.) Fuss (parsley), } \\
\text { Pimpinella anisum L. (anise), Trachyspermum ammi (L.) Sprague (ajwain), } \\
\text { Coriandrum sativum L. (coriander), Foeniculum vulgare Mill. (fennel), Anethum } \\
\text { graveolens L. (dill), Heracleum persicum Desf. ex Fisch., C.A.Mey. \& Avé-Lall. } \\
\text { (Persian hogweed), Ferula assa-foetida L. (asafoetida), Cuminum cyminum L. (cumin) } \\
\text { and Daucus carota L. (carrot) were extracted with } 80 \% \text { methanol and fractionated by } \\
\text { petroleum ether, chloroform, ethyl acetate and methanol, respectively. For different } \\
\text { fractions and total extract of all } 12 \text { samples, cytotoxicity by brine shrimp test (BST) } \\
\text { and MTT assay against cancer and normal cell (foreskin fibroblast cells), antioxidant } \\
\text { effects by FRAP, and total phenols by Folin-Ciocalteu method were measured. } \\
\text { Results: The general toxicity of ethyl acetate fractions (mean of data) was higher than } \\
\text { others in the brine shrimp test (P }<0.05 \text { ). The most cytotoxic fractions against colon } \\
\text { carcinoma (HT-29), breast adenocarcinoma (MDA-MB-231) and alveolar basal } \\
\text { epithelial adenocarcinoma (A549) cell lines were from Ammineae and Peucedaneae } \\
\text { tribes while fruits fractions with high phenol contents and antioxidant powers were } \\
\text { from Ammineae tribe. Conclusion: The Apiaceae fruits have significant biological } \\
\text { effects, therefore the isolation of phytochemical compounds from active fractions with } \\
\text { cytotoxicity is suggested in future studies. }\end{array}$ \\
\hline
\end{tabular}

Abbreviations: TE, Total methanol Extracts; PE, Petroleum Ether fraction; CL, Chloroform fraction; EA, Ethyl Acetate fraction; ME, Methanol residue fraction; BST, Brine Shrimp Test; FRAP, Ferric Reducing Antioxidant Power

* Corresponding authors: goodarzi_s@sina.tums.ac.ir

doi: $10.29252 /$ jmp. 19.76 .46

Received 17 September 2019; Received in revised form 22 August 2020; Accepted 25 August 2020

(C) 2020. Open access. This article is distributed under the terms of the Creative Commons Attribution-NonCommercial 4.0 International License (https://creativecommons.org/licenses/by-nc/4.0/) 


\section{Introduction}

Cancer is the second global cause of death after cardiovascular diseases. In 2015, 17.5 million cases were reported with cancer which 8.7 million of them have died. Despite the fact that the mortality from cancers was reduced in many countries, it is expected that its incidence will be increased. So, it is estimated by 2030 ; there will be 26 million new cancer cases and 17 million cancer deaths per year. Ranking of cancer demonstrated breast, lung and other parts of the respiratory system, and colorectal cancers have more incidences in both sexes $[1,2]$.

According to the prevalence and mortality rate of cancer, the importance of the continuing discovery of new anticancer agents is obvious. The potential of natural products and plantderived compounds for cancer prevention and therapy was the reason for increasing attention to them over the previous few years [3]. On the other hand, over $60 \%$ of anti-cancer drugs have origins from natural sources or are related to them [4]. A significant portion of currently used antitumor drugs are synthetic or semi-synthetic derivatives of effective constituents elucidated from plants [5].

Apiaceae (Umbelliferae) family contains about 450 genera and 3700 species which can be found worldwide [6]. Iran is an important center of diversification of Apiaceae plants which is represented by 121 genera, 360 species and 122 endemic taxa. The fruits of this family have many culinary and medicinal properties $[7,8]$.

The purpose of present comprehensive study was toxicity investigation of common spices from Apiaceae fruits by brine shrimp lethally test (BST) and MTT assay. In addition, their antioxidant activities and total phenols were determined and compared between different tribes of Apiaceae family to find and introduce active fraction(s) for further studies.

\section{Material and Methods}

\subsection{Plant material}

The fruits of selected species of Apiaceae family including Apium graveolens (celery; PMP-687), Bunium persicum (black cumin; PMP-671), Petroselinum crispum (parsley; PMP-686), Pimpinella anisum (anise; PMP-684) and Trachyspermum ammi (ajwain; PMP-682) from Ammineae tribe, Coriandrum sativum (coriander; PMP-677) from Smyrneae tribe, Foeniculum vulgare (fennel; PMP-681) from Seselineae tribe, Anethum graveolens (dill; PMP679), Heracleum persicum (Persian hogweed; PMP-659) and Ferula assa-foetida (asafoetida; PMP-685) from Peucedaneae tribe, Cuminum cyminum (cumin; PMP-670) and Daucus carota (carrot; PMP-676) from Caucalineae tribe were purchased in May 2016 from markets of Tehran, Iran. The plants were identified and deposited in the herbarium of Faculty of Pharmacy, Tehran University of Medical Sciences, Tehran, Iran. The tribes were determined according to previous reference [9].

\subsection{Extraction and fractionation}

The fruits were powdered separately and extracted with $80 \%$ methanol via maceration at room temperature. Total methanol extracts (TE) were fractionated with petroleum ether (PE), chloroform (CL) and ethyl acetate (EA) and the residue was named methanol (ME) fraction. Total extracts and fractions were kept at the refrigerator prior to the test.

\subsection{Brine shrimp lethality test (BST)}

The toxicity of total extracts and different fractions of fruits of Apiaceae family were determined by brine shrimp test. The eggs of Artemia salina Leach (Shilat Center, Tehran, Iran) were hatched in aerated $35 \%$ saltwater under direct light and warmth $\left(28-30{ }^{\circ} \mathrm{C}\right)$. The 
eggs transformed to nauplii $48 \mathrm{~h}$ later. Total extracts and various fractions of fruits were dissolved in normal saline (1\% (v/v) DMSO was used when necessary) to obtain different concentrations of $1-500 \mu \mathrm{g} / \mathrm{ml}$ in tubes containing 15 nauplii of brine shrimp. The control group contained the vehicle used for dilutions. Dead larvae were counted in each well after $24 \mathrm{~h}$ and mortality percentages (p) were determined according to Abbot's formula, $\mathrm{p}=\mathrm{pi}$ $\mathrm{C} / 1$ - $\mathrm{C}$; where pi was the observed mortality rate of each sample and $\mathrm{C}$ means the natural larvae mortality of negative control [10]. The lethal concentration $\left(\mathrm{LC}_{50}\right)$ value of each sample was calculated and reported.

\subsection{Cell culture and MTT Assay}

The colon carcinoma (HT-29), breast adenocarcinoma (MDA-MB-231) and alveolar basal epithelial adenocarcinoma (A549) cell lines were cultured in RPMI 1640 medium and foreskin fibroblast cells (primary culture) was cultured in DMEM medium containing $10 \%$ Fetal bovine serum (FBS) and $1 \%$ penicillinstreptomycin. Cell cultures were maintained at $37{ }^{\circ} \mathrm{C}$ in a humidified $5 \% \mathrm{CO}_{2}$ and $95 \%$ air incubator.

Cytotoxicity studies were performed by MTT assay [11]. Growing cells were incubated into 96-well plates at a density of $1 \times 10^{4}$ cells /well. After $24 \mathrm{~h}$, samples with different concentrations $(10-200 \mu \mathrm{g} / \mathrm{ml})$ were added to wells. $48 \mathrm{~h}$ later, $20 \mu \mathrm{l}$ of $5 \mathrm{mg} / \mathrm{ml}$ MTT reagent in phosphatebuffered serum (PBS) was added to each well. The plates were incubated at $37^{\circ} \mathrm{C}$ for $4 \mathrm{~h}$. Then, the medium was replaced by $100 \mu \mathrm{l}$ pure DMSO to dissolve formazan crystals which were quantified by reading the absorbance at $570 \mathrm{~nm}$ on microplate reader (Anthos, Austria). The cell survival was calculated according to the following equation:
$\%$ Cell viability $=$ Mean absorbance of sample wells/Mean absorbance of control wells $\times 100$

Three independent experiments were performed for each sample. The concentration of samples inducing $50 \%$ growth inhibition $\left(\mathrm{IC}_{50}\right)$ was obtained from a dose response curve.

\subsection{Antioxidant power assay}

Antioxidant activities of different fractions of Apiaceae fruits were determined by ferric reducing antioxidant power (FRAP) assay [12]. In this method, ferric tripyridyltriazine (Fe (III)TPTZ) complex was reduced to its blue colored form (Fe (II)-TPTZ) and the absorbance were measured by spectrophotometer. $50 \mu \mathrm{l}$ of various fractions of fruits with a concentration of $100 \mu \mathrm{g} / \mathrm{ml}$ were added to $1.5 \mathrm{ml}$ of FRAP reagent and incubated at $37{ }^{\circ} \mathrm{C}$. After $10 \mathrm{~min}$, the absorbance of samples was measured at a wavelength of $593 \mathrm{~nm}$. FRAP reagent used as blank and contained $2.5 \mathrm{ml}$ of TPTZ solution $(10 \mathrm{mM})$ in $\mathrm{HCl}(40 \mathrm{mM}), 2.5 \mathrm{ml}$ of $\mathrm{FeCl}_{3}$ $(20 \mathrm{mM})$ and $25 \mathrm{ml}$ of acetate buffer $(0.3 \mathrm{M})$ with $\mathrm{pH}$ 3.6. $\mathrm{FeSO}_{4}$. The standard curve was prepared by $\mathrm{FeSO}_{4} .7 \quad \mathrm{H}_{2} \mathrm{O}$ aqueous solution (125-1000 $\mu \mathrm{M})$ and antioxidant effects of samples were expressed as $\mathrm{mM} \mathrm{Fe} \mathrm{F}^{2+} / 100 \mathrm{~g}$ of fractions.

\subsection{Total phenols determination}

Total phenols amounts of different fractions of extract from Apiaceae fruits were determined by Folin-Ciocalteu method [13]. By the addition of molybdo tungstophosphoric heteropoly anion (Folin-Ciocalteu) reagent with yellow color to samples, phenol compounds were oxidized and molybdo tungstophophate with blue color was created. The maximum absorption of blue color was achieved in alkaline $\mathrm{pH}$, usually by the addition of $\mathrm{NaHCO}_{3}$ or $\mathrm{Na}_{2} \mathrm{CO}_{3} .2 \mathrm{ml}$ of FolinCiocalteu reagent (1:10 diluted with distilled 
water) was mixed with $0.2 \mathrm{ml}$ of methanol solutions of Apiaceae fruits fractions (100 $\mu \mathrm{g} / \mathrm{ml})$. After $5 \mathrm{~min}, 1.5 \mathrm{ml}$ of sodium bicarbonate solution $(60 \mathrm{~g} / \mathrm{L}$ distilled water) was added to the mixture and incubated at room temperature for $90 \mathrm{~min}$. Then the absorbance was measured at $725 \mathrm{~nm}$ by spectrophotometer and the experiment was carried out in triplicate. Different concentrations of Gallic acid methanol solution $(10-100 \mathrm{mg} / \mathrm{ml})$ were used for the preparation of standard curve and total phenols of samples were reported as gallic acid equivalents (GAE; mg of Gallic acid per $g$ of samples).

\subsection{Statistical Analysis}

The data were average of three samples measurements and reported as Mean \pm SD.

Statistical analysis was performed by Graph Pad Prism 5 via One-way ANOVA and post hoc of Tukey, and $\mathrm{P}<0.05$ were considered as a significant difference.

\section{Results}

\subsection{Brine shrimp lethality test (BST)}

Cytotoxic effects of different fractions from Apiaceae fruits were evaluated by BST and MTT assays. Brine shrimp lethality test is a simple, rapid and valid preliminary screening for definition of bioactive cytotoxic chemicals. Mortality ability of all extracts and fractions on Artemia salina were presented in Table 1.

Statistical analysis showed EA fraction of all plants (mean) demonstrated the best mortality rate and had a significant difference with other fractions $(\mathrm{P}<0.05)$ and $\mathrm{PE}$ fraction was the second effective fraction (Fig. 1).

Among EA fractions of plants with $10 \mu \mathrm{g} / \mathrm{ml}$ concentration, $B$. persicum showed the lowest mortality rate with a significant difference with other EA fractions of plants $(\mathrm{P}<0.05)$.

And among PE fractions with $10 \mu \mathrm{g} / \mathrm{ml}$ concentration, D. carota (carrot) is the best and showed significant difference with other PE fractions of plants $(\mathrm{P}<0.05)$ except $A$. graveolens (dill).

Table 1. Cytotoxicity, antioxidant activity and total phenols of different fractions of Apiaceae fruits

\begin{tabular}{|c|c|c|c|c|c|c|}
\hline $\begin{array}{c}\text { Apiaceae } \\
\text { Tribes }\end{array}$ & Plants & Fractions & $\begin{array}{l}\text { Yield* } \\
(\%)\end{array}$ & $\begin{array}{c}\text { LC } \text { s0 of BST }(\mu \mathrm{g} / \mathrm{ml}) \\
\end{array}$ & $\begin{array}{c}\text { FRAP } \\
\left(\mathrm{mM} \mathrm{Fe}^{2+} / \mathrm{g}\right)\end{array}$ & $\begin{array}{l}\text { Total Phenol } \\
\text { (mg GAE/g) }\end{array}$ \\
\hline \multirow{19}{*}{ Ammineae } & \multirow{5}{*}{$\begin{array}{c}\text { Apium } \\
\text { graveolens }\end{array}$} & $\mathrm{PE}$ & 24.0 & $43.89 \pm 0.9$ & $342.10 \pm 18.5$ & $88.59 \pm 0.7$ \\
\hline & & $\mathrm{CL}$ & 17.5 & $246.00 \pm 4.9$ & $642.10 \pm 33.2$ & $218.42 \pm 4.8$ \\
\hline & & EA & 5.0 & $6.05 \pm 0.4$ & $1935.09 \pm 58.5$ & $123.68 \pm 1.9$ \\
\hline & & $\mathrm{ME}$ & 53.5 & $40.04 \pm 1.8$ & $515.78 \pm 19.9$ & $248.68 \pm 9.7$ \\
\hline & & TE & 20.7 & $66.22 \pm 6.3$ & --- & --- \\
\hline & \multirow{5}{*}{$\begin{array}{c}\text { Bunium } \\
\text { persicum }\end{array}$} & $\mathrm{PE}$ & 21.5 & $10.00 \pm 4.2$ & $403.50 \pm 2.6$ & $190.79 \pm 2.0$ \\
\hline & & $\mathrm{CL}$ & 7.6 & $110.34 \pm 7.0$ & $501.75 \pm 9.0$ & $295.60 \pm 3.7$ \\
\hline & & EA & 6.4 & $21.20 \pm 5.4$ & $1742.11 \pm 9.7$ & $278.95 \pm 3.7$ \\
\hline & & $\mathrm{ME}$ & 64.5 & $>500$ & $656.14 \pm 3.8$ & $435.96 \pm 6.6$ \\
\hline & & TE & 6.8 & $>500$ & --- & --- \\
\hline & \multirow{5}{*}{$\begin{array}{l}\text { Petroselinum } \\
\text { crispum }\end{array}$} & $\mathrm{PE}$ & 29.3 & $45.76 \pm 1.2$ & $1682.46 \pm 37.0$ & $260.96 \pm 1.8$ \\
\hline & & $\mathrm{CL}$ & 7.8 & $132.08 \pm 5.0$ & $538.59 \pm 30.5$ & $250.00 \pm 2.6$ \\
\hline & & EA & 4.9 & $6.22 \pm 2.6$ & $738.59 \pm 8.9$ & $410.96 \pm 2.01$ \\
\hline & & $\mathrm{ME}$ & 58.0 & $7.47 \pm 4.9$ & $457.87 \pm 27.5$ & $129.38 \pm 6.7$ \\
\hline & & TE & 18.1 & $10.19 \pm 1.3$ & --- & --- \\
\hline & \multirow{4}{*}{$\begin{array}{l}\text { Pimpinella } \\
\text { anisum }\end{array}$} & $\mathrm{PE}$ & 26.1 & $95.29 \pm 0.9$ & $464.91 \pm 10.0$ & $628.07 \pm 7.5$ \\
\hline & & $\mathrm{CL}$ & 9.1 & $327.54 \pm 6.5$ & $428.07 \pm 19.9$ & $279.38 \pm 10.5$ \\
\hline & & EA & 6.2 & $2.65 \pm 4.6$ & $963.15 \pm 31.5$ & $226.31 \pm 6.5$ \\
\hline & & $\mathrm{ME}$ & 58.6 & $141.5 \pm 4.3$ & $261.40 \pm 17.4$ & $832.90 \pm 4.6$ \\
\hline
\end{tabular}


Table 1. Cytotoxicity, antioxidant activity and total phenols of different fractions of Apiaceae fruits (Continued)

\begin{tabular}{|c|c|c|c|c|c|c|}
\hline $\begin{array}{c}\text { Apiaceae } \\
\text { Tribes }\end{array}$ & Plants & Fractions & $\begin{array}{c}\text { Yield* } \\
\text { (\%) }\end{array}$ & $\begin{array}{c}\text { LC }_{50} \text { of BST } \\
(\mu \mathrm{g} / \mathrm{ml})\end{array}$ & $\begin{array}{c}\text { FRAP } \\
(\mathrm{mM} \mathrm{Fe} 2+/ \mathrm{g}) \\
\end{array}$ & $\begin{array}{l}\begin{array}{l}\text { Total Phenol } \\
\text { (mg GAE/g) }\end{array} \\
\end{array}$ \\
\hline \multirow{6}{*}{$\begin{array}{l}\text { Ammineae } \\
\text { (Continued) }\end{array}$} & \multirow{6}{*}{$\begin{array}{c}\text { Trachyspermum } \\
\text { ammi }\end{array}$} & TE & 11.0 & $438.54 \pm 2.0$ & --- & --- \\
\hline & & $\mathrm{PE}$ & 31.6 & $44.46 \pm 1.5$ & $461.40 \pm 1.7$ & $137.72 \pm 2.7$ \\
\hline & & CL & 11.1 & $78.5 \pm 2.6$ & $631.57 \pm 4.5$ & $350.88 \pm 1.7$ \\
\hline & & EA & 7.2 & $2.77 \pm 0.6$ & $808.77 \pm 3.9$ & $776.75 \pm 5.3$ \\
\hline & & ME & 50.1 & $255.07 \pm 4.6$ & $917.54 \pm 8.9$ & $223.37 \pm 7.9$ \\
\hline & & TE & 12.3 & $49.84 \pm 1.5$ & --- & --- \\
\hline \multirow{5}{*}{ Smyrneae } & \multirow{5}{*}{$\begin{array}{l}\text { Coriandrum } \\
\text { sativum }\end{array}$} & $\mathrm{PE}$ & 15.8 & $116.63 \pm 5.7$ & $782.45 \pm 11.3$ & $172.36 \pm 4.6$ \\
\hline & & CL & 6.6 & $275.37 \pm 12.5$ & $663.15 \pm 6.9$ & $112.28 \pm 4.8$ \\
\hline & & EA & 10.5 & $3.16 \pm 4.3$ & $701.75 \pm 3.5$ & $364.03 \pm 2.9$ \\
\hline & & ME & 67.1 & $27.12 \pm 4.0$ & $885.96 \pm 5.8$ & $453.07 \pm 1.4$ \\
\hline & & $\mathrm{TE}$ & 7.2 & $73.45 \pm 3.2$ & --- & --- \\
\hline \multirow{5}{*}{ Seselineae } & \multirow{5}{*}{$\begin{array}{l}\text { Foeniculum } \\
\text { vulgare }\end{array}$} & $\mathrm{PE}$ & 15.1 & $41.27 \pm 3.9$ & $1470.18 \pm 52.8$ & $100.00 \pm 2.7$ \\
\hline & & CL & 10.2 & $19.78 \pm 6.6$ & $115.78 \pm 1.4$ & $190.13 \pm 4.0$ \\
\hline & & EA & 6.3 & $3.44 \pm 0.3$ & $654.38 \pm 25.1$ & $263.60 \pm 2.3$ \\
\hline & & ME & 68.4 & $>500$ & $1821.05 \pm 56.5$ & $284.65 \pm 6.0$ \\
\hline & & $\mathrm{TE}$ & 8.3 & $>500$ & --- & --- \\
\hline \multirow{15}{*}{ Peucedaneae } & \multirow{5}{*}{$\begin{array}{l}\text { Anethum } \\
\text { graveolens }\end{array}$} & $\mathrm{PE}$ & 13.9 & $2.71 \pm 0.6$ & $126.27 \pm 6.7$ & $160.52 \pm 6.0$ \\
\hline & & CL & 6.3 & $22.57 \pm 6.6$ & $484.21 \pm 13.8$ & $156.14 \pm 3.8$ \\
\hline & & EA & 8.8 & $2.09 \pm 0.3$ & $859.64 \pm 43.7$ & $228.95 \pm 4.7$ \\
\hline & & ME & 71.0 & $190.88 \pm 5.0$ & $219.29 \pm 10.3$ & $71.93 \pm 1.5$ \\
\hline & & $\mathrm{TE}$ & 6.6 & $>500$ & --- & --- \\
\hline & \multirow{5}{*}{$\begin{array}{l}\text { Heracleum } \\
\text { persicum }\end{array}$} & $\mathrm{PE}$ & 14.4 & $17.65 \pm 5.1$ & $1471.05 \pm 16.0$ & $125.00 \pm 2.8$ \\
\hline & & CL & 9.9 & $40.94 \pm 5.2$ & $484.21 \pm 2.9$ & $76.88 \pm 5.4$ \\
\hline & & EA & 7.9 & $1.80 \pm 0.4$ & $1652.63 \pm 23.9$ & $128.95 \pm 0.5$ \\
\hline & & ME & 67.8 & $75.81 \pm 5.4$ & $702.58 \pm 12.3$ & $103.07 \pm 2.0$ \\
\hline & & $\mathrm{TE}$ & 11.3 & $23.11 \pm 1.0$ & --- & --- \\
\hline & \multirow{5}{*}{$\begin{array}{c}\text { Ferula } \\
\text { assa-foetida }\end{array}$} & $\mathrm{PE}$ & 13.0 & $7.77 \pm 1.5$ & $326.28 \pm 5.2$ & $264.91 \pm 6.4$ \\
\hline & & $\mathrm{CL}$ & 11.0 & $297.71 \pm 5.4$ & $560.53 \pm 4.1$ & $415.35 \pm 3.9$ \\
\hline & & EA & 6.6 & $9.21 \pm 1.8$ & $1084.21 \pm 11.5$ & $541.23 \pm 2.1$ \\
\hline & & $\mathrm{ME}$ & 69.4 & $>500$ & $1294.74 \pm 12.6$ & $109.65 \pm 1.1$ \\
\hline & & $\mathrm{TE}$ & 12.6 & $44.52 \pm 3.0$ & --- & --- \\
\hline \multirow{10}{*}{ Caucalineae } & \multirow{5}{*}{$\begin{array}{l}\text { Cuminum } \\
\text { cyminum }\end{array}$} & $\mathrm{PE}$ & 22.4 & $33.68 \pm 1.5$ & $339.47 \pm 6.3$ & $39.91 \pm 2.7$ \\
\hline & & CL & 8.6 & $10.59 \pm 4.2$ & $436.84 \pm 3.7$ & $135.52 \pm 1.0$ \\
\hline & & EA & 8.0 & $1.62 \pm 1.5$ & $847.36 \pm 2.9$ & $243.42 \pm 1.5$ \\
\hline & & ME & 61.0 & $>500$ & $439.47 \pm 2.6$ & $117.98 \pm 3.6$ \\
\hline & & $\mathrm{TE}$ & 11.9 & $>500$ & --- & --- \\
\hline & \multirow{5}{*}{$\begin{array}{l}\text { Daucus } \\
\text { carota }\end{array}$} & $\mathrm{PE}$ & 21.5 & $5.11 \pm 0.4$ & $389.47 \pm 9.6$ & $148.24 \pm 2.5$ \\
\hline & & CL & 8.0 & $403.43 \pm 3.9$ & $663.15 \pm 21.1$ & $72.36 \pm 3.2$ \\
\hline & & EA & 6.3 & $6.16 \pm 0.3$ & $508.77 \pm 27.5$ & $161.40 \pm 3.7$ \\
\hline & & ME & 64.2 & $>500$ & $542.10 \pm 34.6$ & $52.63 \pm 1.3$ \\
\hline & & TE & 9.0 & $395.13 \pm 0.7$ & --- & --- \\
\hline \multirow{2}{*}{\multicolumn{2}{|c|}{$\begin{array}{l}\text { Vitamin E } \\
\text { BHA }\end{array}$}} & --- & --- & --- & $3130.7 \pm 2.2$ & --- \\
\hline & & --- & --- & --- & $8800.3 \pm 6.4$ & --- \\
\hline
\end{tabular}

* Yield (\%) calculated based on fraction (g)/total extract (g); PE: Petroleum ether fraction, CL: Chloroform fraction, EA: Ethyl acetate fraction, ME: Methanol fraction, TE: Total Extract 


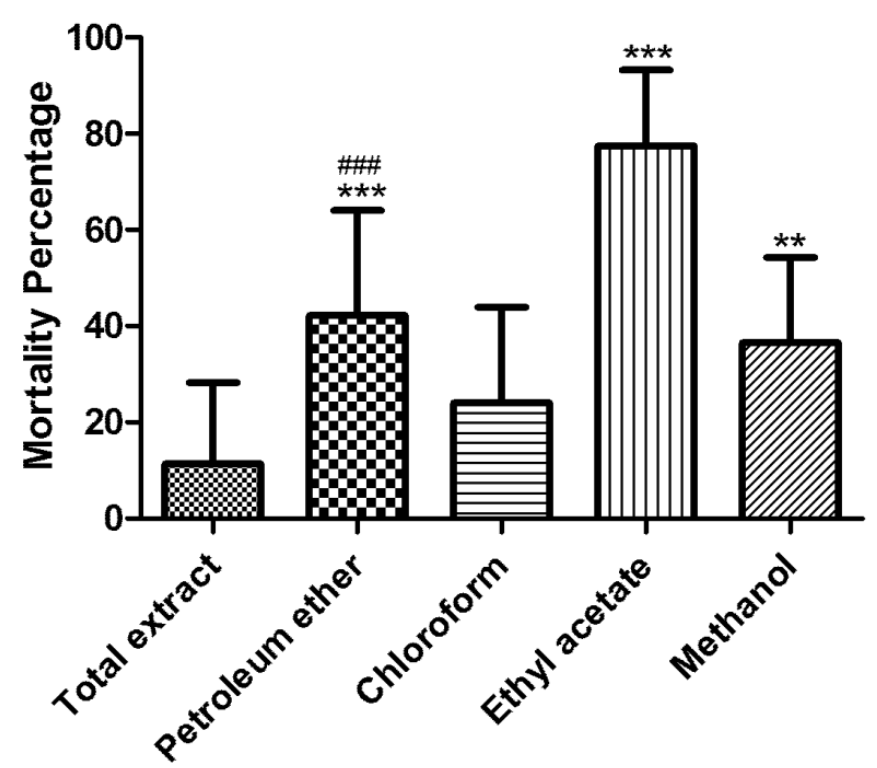

Fig. 1. BST mortality percentage of all fractions $(10 \mu \mathrm{g} / \mathrm{ml})$ of Apiaceae fruits, $* * \mathrm{P} \leq 0.05$, $* * * \mathrm{P} \leq 0.01$ with total extract, ${ }^{\# \#} \mathrm{P} \leq 0.05$ with ethyl acetate fraction

\subsection{MTT Assay}

Cytotoxic fractions of Apiaceae fruits against cancer and normal cell lines were demonstrated in Table 2. Other samples showed $\mathrm{IC}_{50}$ upper than $200 \mu \mathrm{g} / \mathrm{ml}$.

Most cytotoxic fractions were active against breast adenocarcinoma (MDA-MB-231) including PE of $P$. anisum, CL of $F$. assa-foetida, CL of $H$. persicum, $\mathrm{PE}$ of A. graveolens (celery), $\mathrm{PE}$ of T. ammi and $\mathrm{PE}$ of $D$. carota with $\mathrm{IC}_{50}$ equal to 147.76, 155.65, 177.61, 184.36, 195.83 and $197.00 \mu \mathrm{g} / \mathrm{ml}$, respectively. Only CL and PE of $F$. assa-foetida demonstrated cytotoxicity on other cancer cell lines including CL and PE fractions with $\mathrm{IC}_{50}$ equal to 151.94 and $158.03 \mu \mathrm{g} / \mathrm{ml}$ on $\mathrm{A} 549$ alveolar and $\mathrm{CL}$ fraction with $\mathrm{IC}_{50}$ equal to $144.16 \mu \mathrm{g} / \mathrm{ml}$ against HT-29 colon cell lines.

Near all fractions of fruits demonstrated $\mathrm{IC}_{50}$ value of upper than $200 \mu \mathrm{g} / \mathrm{ml}$ against normal cell line except CL of $F$. assa-foetida and A. graveolens (celery) with $\mathrm{IC}_{50}$ equal to 140.66 and $193.71 \mu \mathrm{g} / \mathrm{ml}$, respectively.

It was considerable greatest cytotoxic fractions against colon carcinoma (HT-29), breast adenocarcinoma (MDA-MB-231) and alveolar basal epithelial adenocarcinoma (A549) cell lines were from Ammineae and Peucedaneae tribes of Apiaceae family.

\subsection{Antioxidant power assay}

Total antioxidant activities of different fractions of Apiaceae fruits were measured based on $\mathrm{FeSO}_{4}$ standard curve $\left(y=0.001 x+0.049, r^{2}\right.$ $=0.932$ ) and reported in Table 1 in comparison to natural (vitamin E) and synthetic (BHA; butylated hydroxyanisole) antioxidants.

Antioxidant activities of some fractions of A. graveolens, B. persicum and P. crispum from Ammineae tribe, $F$. vulgare from Seselineae tribe, $H$. persicum and $F$. assa-foetida from Peucedaneae tribe were higher than others. All fractions of Apiaceae fruits have been shown no considerable antioxidant effects compare to vitamin $\mathrm{E}$ and BHA. On the other side, EA fraction of all fruits demonstrated greatest or significant reducing capacity among different fractions except $F$. vulgare and $D$. carota. 
Table 2. Cytotoxic fractions of Apiaceae fruits against cancer and normal cell lines.

\begin{tabular}{|c|c|c|c|c|}
\hline \multirow{2}{*}{ Samples } & \multicolumn{4}{|c|}{ IC $_{50}$ of MTT assay } \\
\hline & HT-29 & MDA-MB-231 & A549 & fibroblast \\
\hline $\mathrm{PE}^{\mathrm{a}}$ of $P$. anisum & $>200$ & $147.76 \pm 3.12$ & $>200$ & $>200$ \\
\hline PE of T. ammi & $>200$ & $195.83 \pm 2.44$ & $>200$ & $>200$ \\
\hline PE of A. graveolens & $>200$ & $184.36 \pm 2.93$ & $>200$ & $>200$ \\
\hline $\mathrm{CL}^{\mathrm{b}}$ of $A$. graveolens & $>200$ & $>200$ & $>200$ & $193.71 \pm 2.64$ \\
\hline CL of $H$. persicum & $>200$ & $177.61 \pm 1.24$ & $>200$ & $>200$ \\
\hline PE of $F$. assa-foetida & $>200$ & $>200$ & $158.03 \pm 1.63$ & $>200$ \\
\hline CL of $F$. assa-foetida & $144.16 \pm 1.25$ & $>200$ & $>200$ & $>200$ \\
\hline CL of $F$. assa-foetida & $>200$ & $155.65 \pm 2.86$ & $>200$ & $>200$ \\
\hline CL of $F$. assa-foetida & $>200$ & $>200$ & $151.94 \pm 1.74$ & $>200$ \\
\hline CL of $F$. assa-foetida & $>200$ & $>200$ & $>200$ & $140.66 \pm 2.50$ \\
\hline PE of D. carota & $>200$ & $197.00 \pm 3.47$ & $>200$ & $>200$ \\
\hline
\end{tabular}

Results are expressed as $\mathrm{IC}_{50}$ value $(\mu \mathrm{g} / \mathrm{ml})$, mean of three determinations. ${ }^{\text {a }}$ PE: petroleum ether fraction; ${ }^{\mathrm{b}} \mathrm{CL}$ : chloroform fraction; P. anisum: Pimpinella anisum, T. ammi: Trachyspermum ammi; A. graveolens: Apium graveolens; H. persicum: Heracleum persicum; F. assa-foetida: Ferula assa-foetida; D. carota: Daucus carota

\subsection{Total phenols determination}

Total phenols contents of different fractions of Apiaceae fruits were determined according to the standard curve of Gallic acid $\left(y=0.0076 x, r^{2}=\right.$ 0.999) and reported in Table 1. Some fractions of P. anisum and T. ammi from Ammineae tribe had the highest phenol contents among others. ME and EA were fractions of fruits with higher amounts of phenols except PE fraction of $D$. carota and P. anisum (after ME) which contained greatest content of phenols. Statistical analysis of total phenols showed no difference between fractions $(\mathrm{P}<0.05)$ (Figure 2).

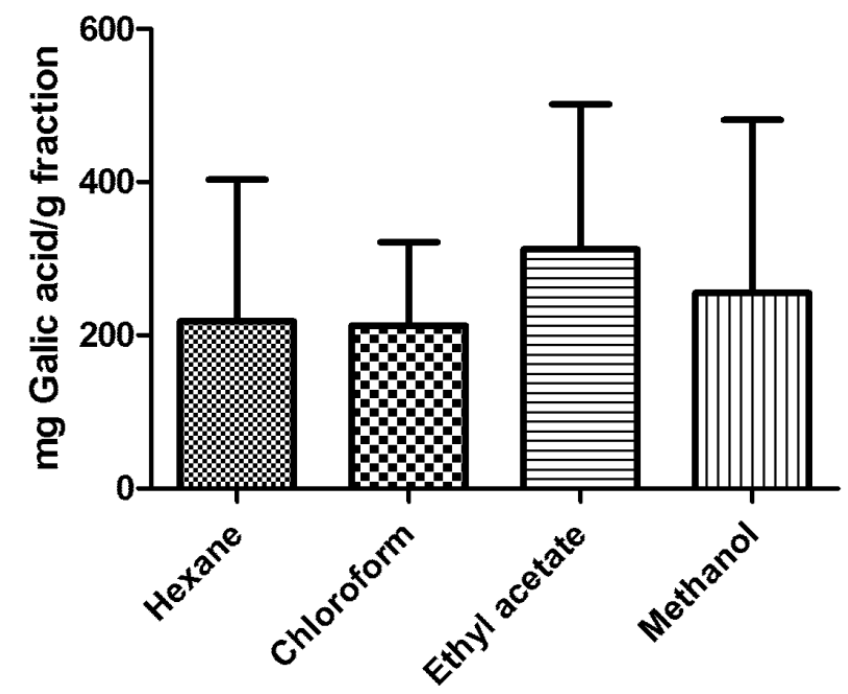

Fig. 2. Total phenols contents in all fractions of Apiaceae fruits 


\section{Discussion}

The fruits of Apiaceae family are widely used as spices around the world for culinary and medicinal properties $[14,15]$. One of the important properties of consumption of plants as food is the prevention of chronic diseases including cancers. In the present study, cytotoxicity, antioxidant effects and total phenols of different fractions of twelve fruits from the Apiaceae family were measured and compared in various tribes of Apiaceae family.

The results were demonstrated cytotoxicity of almost all EA fractions and some other fractions of fruits measured by BST method were comparable with well-known cytotoxic alkaloid, berberine hydrochloride with $\mathrm{LC}_{50}$ of $26 \mu \mathrm{g} / \mathrm{ml}$ [16]. In fruits from Ammineae tribe, EA of A. graveolens, PE and EA of B. persicum, EA and ME of $P$. crispum, EA of $P$. anisum and EA of $T$. ammi had significant cytotoxic activities. A previous study about toxicity investigation on A. salina by traditional medicinal plants of Northern Peru showed $\mathrm{LC}_{50}$ of aqueous and ethanol crude extracts of $A$. graveolens aerial parts as 171 and $25 \mu \mathrm{g} / \mathrm{ml}$, respectively [17]. There was an opposite report for none lethality activities of different extracts of $A$. graveolens of Pakistan on brine shrimp [18]. An investigation in Oman demonstrated ethyl acetate and hydro alcoholic extracts of the leaves of $P$. crispum killed the shrimp larvae with $\mathrm{LC}_{50}$ values equal to 51.95 and $88.15 \mu \mathrm{g} / \mathrm{ml}$, respectively [19]. Assessment of brine shrimp cytotoxic activity of T. ammi seeds ethanol extract in Sundarbans mangrove forest region revealed $\mathrm{LC}_{50}$ and $\mathrm{LC}_{90}$ as 35.48 and $66.83 \mu \mathrm{g} / \mathrm{ml}$, respectively [20]. The toxicity of crude extracts of present study was near to mentioned results.

EA of C. sativum from Smyrneae tribe and EA and CL of $F$. vulgare from Seselineae tribe were effective against $A$. salina. Aqueous and ethanol extracts of $C$. sativum aerial parts with $\mathrm{LC}_{50}$ of 22 and $0.015 \mu \mathrm{g} / \mathrm{ml}$, and $F$. vulgare with $\mathrm{LC}_{50}$ of $>10000$ and $2.75 \mu \mathrm{g} / \mathrm{ml}$ exhibited their BST activity [17]. Another study on Sudanese plants demonstrated $\mathrm{LC}_{50}$ of 893.97 and $0.012 \mu \mathrm{g} / \mathrm{ml}$ for $F$. vulgare aqueous and ethanol extracts, respectively [21]. The data of present work about crude hydroalcoholic extracts of $C$. sativum and $F$. vulgare from Iran showed weaker toxicity than alcoholic extracts of Peru and Sudanese plants.

EA, PE and CL of A. graveolens, EA, PE and $\mathrm{CL}$ of $H$. persicum, and $\mathrm{PE}$ and $\mathrm{EA}$ of F. assa-foetida from Peucedaneae tribe showed potent effects as cytotoxic agents. Cytotoxicity of the aerial part of $A$. graveolens (dill) crude extract against brine shrimps showed it was toxic with $\mathrm{LC}_{50}$ value of $51.29 \mu \mathrm{g} / \mathrm{ml}$ [22]. A previous report revealed essential oil of $H$. persicum $\left(\mathrm{LC}_{50}\right.$ equal to $0.0071 \mu \mathrm{l} / \mathrm{ml}$ ) was known as active fraction in BST assay [23]. Our data about toxicity of crude extract of $H$. persicum was stronger than previous mentioned result.

EA and CL of C. cyminum, and PE and EA of D. carota from Caucalineae tribe were effective via brine shrimp bioassay. There were no previous reports about brine shrimp bioactivities of these plants.

Further cytotoxic investigations of different fractions of Apiaceae fruits were done by MTT assays against three cancer cell lines (HT-29, MDA-MB-231 and A549) and a normal foreskin fibroblast cell line. According to standard of National Cancer Institute (NCI) and Geran protocol, when a crude extract showed an $\mathrm{IC}_{50}$ less than $20 \mu \mathrm{g} / \mathrm{ml}$, it was highly cytotoxic and active against cancer cell lines, when $\mathrm{IC}_{50}$ equal to $21-200 \mu \mathrm{g} / \mathrm{ml}$, it is moderately cytotoxic, when $\mathrm{IC}_{50}$ equal to $201-500 \mu \mathrm{g} / \mathrm{ml}$, it is weakly cytotoxic and when $\mathrm{IC}_{50}$ is upper than $501 \mu \mathrm{g} / \mathrm{ml}$, it isn't cytotoxic [24]. 
In details, all fractions showed $\mathrm{IC}_{50}$ higher than $200 \mu \mathrm{g} / \mathrm{ml}$ (weak or non-cytotoxic) except CL of $F$. assa-foetida on HT-29 with IC $_{50}$ equal to $144.16 \mu \mathrm{g} / \mathrm{ml} ; \mathrm{PE}$ and CL of $F$. assa-foetida on A549 with $\mathrm{IC}_{50}$ equal to 158.03 and 151.94 $\mu \mathrm{g} / \mathrm{ml}$, respectively and $\mathrm{CL}$ of $A$. graveolens (celery) and $F$. assa-foetida on foreskin fibroblast cell line with IC $_{50}$ equal to 193.71 and $140.66 \mu \mathrm{g} / \mathrm{ml}$, respectively.

Based on this criterion, all fractions of fruits demonstrated no significant cytotoxic effects on cancer and normal cell lines. But there were maybe potent cytotoxic compounds in the most cytotoxic fractions of them including $P$. anisum, $F$. assa-foetida, $H$. persicum, A. graveolens (celery), T. ammi and D. carota, or they were maybe active against other cancer cell lines. It was interesting that most of cytotoxic fractions were from Ammineae and Peucedaneae tribes of Apiaceae. There were little reports about cytotoxic evaluation of extracts or fractions of mentioned plants. Antiproliferative effects of A. graveolens seeds extract has been confirmed on Dalton's lymphoma ascites (DLA) and mouse lung fibroblast (L929) cell lines by induction of apoptosis, DNA fragmentation and morphological changes [25]. Another study showed hexane extract of $A$. graveolens at concentrations of 100 and $200 \mu \mathrm{g} / \mathrm{ml}$ had the best cytotoxic activity on Rhabdomyosarcoma (RD) cell line [26]. In present research, more fractions of Apiaceae fruits were active against breast cancer (MDA-MB-231) cell line including PE of $P$. anisum and T. ammi from Ammineae tribe with $\mathrm{IC}_{50}$ equal to 147.76 and $195.83 \mu \mathrm{g} / \mathrm{ml}$, respectively. Previous investigations showed treatment of liver HepG2 cell lines with anise seeds essential oil could exhibited a significant cytotoxicity [27]. In addition, ethanol extract of $P$. anisum revealed antiproliferative and apoptotic effects toward human prostate cancer cell line (PC-3) with $\mathrm{IC}_{50}$ value of $400 \mu \mathrm{g} / \mathrm{ml}$ [28]. Cytotoxicity of T. ammi essential oil on colon carcinoma cells was confirmed with an $\mathrm{IC}_{50}$ value of $9.6 \mu \mathrm{g} / \mathrm{ml}$, too [29]. It was shown phytochemicals including thymol, $\gamma$-terpinene and $p$-cymene played an important role in anticancer activity of essential oil and hexane extracts of ajwain [30].

PE of A. graveolens (dill) and CL of $H$. persicum and $F$. assa-foetida from Peucedaneae tribe with $\mathrm{IC}_{50}$ equal to $184.36,177.61$ and $155.65 \mu \mathrm{g} / \mathrm{ml}$, respectively and PE of $D$. carota from Caucalineae tribe with $\mathrm{IC}_{50}$ equal to 197.00 $\mu \mathrm{g} / \mathrm{ml}$ showed cytotoxicity against breast cancer cell line, too. In before experiment, cytotoxicity evaluation of $H$. persicum aerial parts essential oil on three human cancer cell lines (HeLa, LS180 and Raji) demonstrated no effects with $\mathrm{IC}_{50}$ more than $2 \mathrm{mg} / \mathrm{ml}$ [31]. Cytotoxicity of carrot essential oil was reported by $\mathrm{IC}_{50}$ of 35.3 and $46.1 \mu \mathrm{g} / \mathrm{ml}$ on green monkey kidney (VERO) and human pharynx squamous cell carcinoma $(\mathrm{FaDu})$ cell lines, respectively. Carotol, an important constituent of $D$. carota essential oil exhibited moderate cytotoxicity on both cell lines with no selectivity [32]. In another study, $D$. carota essential oil induced selective apoptosis in acute myeloid leukemia (AML) cell line via a MAPK-dependent mechanism [33]. It was interesting that most of cytotoxic plants fractions were from Ammineae and Peucedaneae tribes of Apiaceae.

Antioxidant activities of some fractions of A. graveolens, B. persicum and $P$. crispum, $F$. vulgare, $H$. persicum and $F$. assa-foetida were higher than others but it was not comparable with natural (vitamin E) and synthetic (BHA; Butylated hydroxyanisole) antioxidants. EA fraction of all fruits except $F$. vulgare and D. carota demonstrated greatest or significant reducing capacity among different fractions. The 
previous study showed methanol extract of A. graveolens seeds exhibited better antioxidant effects as $\mathrm{Fe}^{+2}$ chelating, reducing power activities, and the amounts of total phenols were higher in comparison to other extracts [34]. Another research demonstrated $P$. anisum extract showed the strongest radical scavenging activity among seven Apiaceae fruits from Iran. In addition, ethyl acetate fraction of $P$. anisum exhibited the highest antioxidant activity and flavonoid content [35]. P. crispum exhibited DPPH free radical-scavenging activity and cupric reducing antioxidant capacity [36]. There were no reports about antioxidant activities of different fractions of mentioned plants.

Total phenol contents of ME of $P$. anisum, EA of T. ammi and PE of P. anisum from Ammineae tribe were higher than other samples. According to previous results, anethole and thymol were the most abundant components of $P$. anisum and T. ammi essential oil which have phenol structures [37, 38]. It was interesting that all plants with potent antioxidant activities and high phenol contents were from Ammineae tribe of Apiaceae.

\section{Conclusion}

The brine shrimp lethally test is an ideal method in the initial biological screening of a broad range of phytochemical compounds including toxic components. Present investigation demonstrated despite potent larvicidal effects of EA fractions from Apiaceae fruits against $A$. salina, they didn't demonstrate considerable cytotoxicity against cancer and

\section{References}

1. Fitzmaurice $C$, Allen $C$, Barber $R M$, Barregard L, Bhutta ZA, Brenner H, Dicker DJ, Chimed-Orchir O, Dandona R and Dandona L. Global, regional, and national cancer incidence, normal cell lines. Statistical analysis also confirmed that EA fraction is the best cytotoxic fraction and there was no significant difference between all fractions from the point of view of total phenols. Almost more cytotoxic fractions belong to fruits from Peucedaneae tribe while all plants with high phenol contents and antioxidant powers were from Ammineae tribe of Apiaceae. Secondary metabolites in active cytotoxic fractions have potential to act as toxic compounds on other cancer cell lines. In addition, there were not seen significant correlations between cytotoxicity, antioxidant and total phenols of different fractions from Apiaceae fruits.

\section{Author contributions}

Z.T., S.G. and E.M. conceived of the idea, planned and supervised the experiments. M.R., Sh.M., F.M., M.A., F.K., and B.Kh. carried out the experiments. M.P.H, S.T., M.J.T. S.J.N., and M.Sh. helped to perform experiments and analyzed the data. Z.T., M.P.H. and S.G. discussed the results and contributed to the final manuscript.

\section{Conflict of interest}

The authors declare that there is no conflict of interest.

\section{Acknowledgements}

This research were theses of Pharm D and supported by a grant of Medicinal Plants Research Center, Faculty of Pharmacy, Tehran University of Medical Sciences (No. 35390).

mortality, years of life lost, years lived with disability, and disability-adjusted life-years for 32 cancer groups, 1990 to 2015: a systematic analysis for the global burden of disease study. JAMA Oncology 2017; 3(4): 524-48. 
2. Thun MJ, DeLancey JO, Center MM, Jemal A, Ward EM. The global burden of cancer: priorities for prevention. Carcinogenesis 2009; 31(1): 100-10.

3. Haque MU, Ferdiousi N, Sajon SR. Anticancer agents derived from plant and dietary sources: a review. IJP 2016; 32: 55-66.

4. Cragg GM, Kingston DG, Newman DJ. Anticancer agents from natural products: CRC press; 2011.

5. Kinghorn A, Farnsworth $N$, Soejarto $D$, Cordell G, Swanson S, Pezzuto J, Wani M and Wall M. Novel strategies for the discovery of plant-derived anticancer agents. Pharm. Biol. 2003; 41(sup1): 53-67.

6. Pimenov MG, Leonov MVe. The genera of the Umbelliferae: a nomenclator: Royal Botanic Gardens, Kew; 1993.

7. Mozaffarian V. A Dictionary of Iranian Plant Names. Tehran: Farhang Moaser Pub, 1996. (In Persian).

8. Amiri MS and Joharchi MR. Ethnobotanical knowledge of Apiaceae family in Iran: A review. Avicenna J. Phytomedicine 2016; 6(6): 621.

9. Zargari A. Identification method of plant. Tehran: Amirkabir Pub, 1962. Persian.

10. Tofighi $Z$, Asgharian $P$, Goodarzi S, Hadjiakhoondi A, Ostad SN, Yassa N. Potent cytotoxic flavonoids from Iranian Securigera securidaca. Med. Chem. Res. 2014; 23(4): 1718-24. 11. Goodarzi S, Nateghpour $M$, Asgharian $P$, Hadjiakhoondi A, Yassa N, Tavakoli S, Mirzaei J, Farivar L, Motevalli Haghi A and Tofighi Z. Antimalarial and cytotoxic activities of roots and fruits fractions of Astrodaucus persicus extract. IJBMS. 2017; 20(12): 1318.

12. Goodarzi S, Hadjiakhoondi A, Yassa N, Khanavi $M$ and Tofighi Z. Essential oils chemical composition, antioxidant activities and total phenols of Astrodaucus persicus. IJBMS 2016; 19(2): 159.
13. Tofighi Z, Es-haghi A, Asl MM, Tajic AR, Navai MS, Tavakoli S, Hadjiakhoondi A and Yassa N. Investigation of chemical keys for relationship between plants and their unifloral honeys by hydrodistillation and SPME and biological activities of honeys. Eur. Food Res. Technol. 2014; 238(4): 665-73.

14. Goodarzi S, Tabatabaei MJ, Mohammad Jafari R), Mofasseri M and Tofighi Z. Cuminum cyminum fruits as source of luteolin- 7-Oglucoside, potent cytotoxic flavonoid against breast cancer cell lines. Nat. Prod. Res. 2020; 34(11): 1602-1606.

15. Goodarzi S, Hadjiakhoondi A, Yassa N, Khanavi $\mathrm{M}$ and Tofighi $\mathrm{Z}$. New benzodioxole compounds from the root extract of Astrodaucus persicus. IJPR 2016; 15(4): 901-906.

16. Gohari AR, Saeidnia S, Gohari MR, MoradiAfrapoli F, Malmir M, Hadjiakhoondi A. Bioactive flavonoids from Satureja atropatana Bonge. Nat. Prod. Res. 2009; 23(17): 1609-14.

17. Bussmann R, Malca G, Glenn A, Sharon D, Nilsen B, Parris B, Dubose D, Ruiz D, Saleda J, Martinez M, Carillo L, Walker K, Kuhlman A and Townesmith A. Toxicity of medicinal plants used in traditional medicine in Northern Peru. $J$. Ethnopharmacol. 2011; 137(1): 121-40.

18. Shad AA, Shah HU, Bakht J, Choudhary MI and Ullah J. Nutraceutical potential and bioassay of Apium graveolens L. grown in Khyber Pakhtunkhwa-Pakistan. J. Med. Plant. Res. 2011; 5(20): 5160-6.

19. Al-Haadi AMH, Al Rahbi SS, Akhtar MS, Said S, Weli A and Al Riyami Q. Phytochemical screening, antibacterial and cytotoxic activities of Petroselinum crispum leaves grown in Oman. IJPR 2013; 9(1): 61-5.

20. Sharker SM, Shahid IJ. Assessment of antibacterial and cytotoxic activity of some locally used medicinal plants in Sundarban 
mangrove forest region. Afr. J. Pharm. Pharmacol. 2010; 4(2): 066-9.

21. Hilmi Y, Abushama MF, Abdalgadir $\mathrm{H}$, Khalid A and Khalid H. A study of antioxidant activity, enzymatic inhibition and in vitro toxicity of selected traditional sudanese plants with anti-diabetic potential. BMC Complement. Altern. 2014; 14(1): 149.

22. Ksouri A, Dob T, Belkebir A, Lamari L, Krimat $S$ and Metidji $H$. Total phenolic, antioxidant, antimicrobial activities and cytotoxicity study of wild Anethum graveolens L. Int. J. Pharmacogn. Phytochem. Res. 2015; 7: 1025-32.

23. Moshafi MH, Sharififar F, Dehghan G and Ameri A. Bioassay screening of the essential oil and various extracts of fruits of Heracleum persicum Desf. and rhizomes of Zingiber officinale Rosc. using brine shrimp cytotoxicity assay. IJPR 2010; 8(1): 59-63.

24. Aghaei M, Ghanadian M, Faez F and Esfandiary E. Cytotoxic activities of Euphorbia kopetdaghi against OVCAR-3 and EJ-138 cell lines. J. Herb. Med. Pharmacol. 2015; 4(2): 49-52. 25. Subhadradevi V, Kalathil K, Asokkumar K, Umamaheswari M, Jagannath P. Induction of apoptosis and cytotoxic activities of Apium graveolens Linn. using in vitro models. Middle East J. Sci. Res. 2011; 9(1): 90-94

26. Rakad M, Jumaily A. Evaluation of anticancer activities of crude extracts of Apium graveolens L. Seeds in two cell lines, RD and L20B in vitro. Iraqi J. Cancer Med. Genet. 2010; 3(2): 20-3.

27. Abdel-Reheem MA and Oraby MM. Antimicrobial, cytotoxicity, and necrotic ripostes of Pimpinella anisum essential oil. Ann. Agric. Sci. 2015; 60(2): 335-40.

28. Kadan S, Rayan M and Rayan A. Anticancer activity of anise (Pimpinella anisum L.) seed extract. The Open Nutraceuticals J. 2013; 6(1): $1-5$.

29. Vitali LA, Beghelli D, Nya PCB, Bistoni O, Cappellacci L, Damiano S, Lupidi G, Maggi F, Orsomando $G$ and Papa F. Diverse biological effects of the essential oil from Iranian Trachyspermum ammi. Arab. J. Chem. 2016; 9(6): 775-86.

30. Abdel-Hameed E-SS, Bazaid SA, Al Zahrani O, El-Halmouch Y, El-Sayed MM and El-Wakil E. Chemical composition of volatile components, antimicrobial and anticancer activity of n-hexane extract and essential oil from Trachyspermum ammi L. seeds. Orient. J. Chem. 2014; 30(4): 1653-62.

31. Firuzi O, Asadollahi M, Gholami $M$ and Javidnia K. Composition and biological activities of essential oils from four Heracleum species. Food Chem. 2010; 122(1): 117-22.

32. Sieniawska E, Swiatek L, Rajtar B, Koziol E, Polz-Dacewicz $M$ and Skalicka-Wozniak K. Carrot seed essential oil-Source of carotol and cytotoxicity study. Ind. Crops Prod. 2016; 92: 109-15.

33. Tawil M, Bekdash A, Mroueh M, Daher CF and Abi-Habib RJ. Wild carrot oil extract is selectively cytotoxic to human acute myeloid leukemia cells. Asian Pac. J. Cancer Prev. 2015; 16(2): 761-7.

34. AYDEMIR $T$ and Becerik $S$. Phenolic content and antioxidant activity of different extracts from Ocimum basilicum, Apium graveolens and Lepidium sativum seeds. J. Food Biochem. 2011; 35(1): 62-79.

35. Nickavar B and Abolhasani FA-S. Screening of antioxidant properties of seven Umbelliferae fruits from Iran. PJPS 2009; 22(1): 30-5.

36. Mert A and Timur M. Essential oil and fatty acid composition and antioxidant capacity and total phenolic content of parsley seeds 
(Petroselinum crispum) grown in Hatay region. Indian J. Pharm. Educ. Res. 2017; 51(3): 437-40. 37. Olgun Ç, Ozkan OE, Guney B, Pattabanoglu ES, Guney K and Gur M. Chemical composition and antimicrobial activity in cold press oil of fennel, Anise, white and black mustard seeds. Indian J. Pharm. Educ. Res. 2017; 51(3): 200-04. 38. Mirzahosseini SM, Noori SAS, Amanzadeh Y, Javid MG and Howyzeh MS. Phytochemical assessment of some native ajowan (Therachyspermum ammi L.) ecotypes in Iran. Ind. Crops Prod. 2017; 105: 142-7.
How to cite this article: Tofighi Z, Pirali Hamedani M, Tavakoli S, Tabatabaei MJ, Rabei M, Mohtadi Sh, Mirghaffari F, Afshani M, Kahrizi F, Khodabandeloo B, JafariNodooshan S, Shirzad M, Motevaseli E, Goodarzi S. Screening of Apiaceae fruits discovered natural resources with considerable biological potential. Journal of Medicinal Plants 2020; 19(76): 46-58. doi: $10.29252 /$ jmp. 19.76 .46 
غربالكرى ميوههاى خانواده جتريان، به عنوان منابع طبيعى بالقوه داراى خواص بيولوزيك

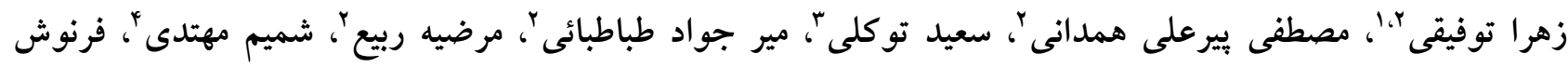

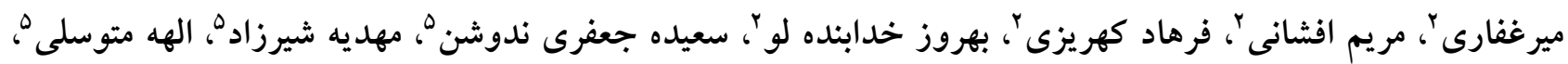

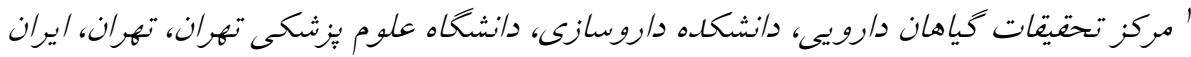

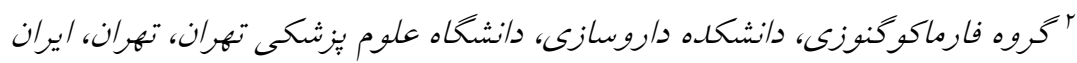

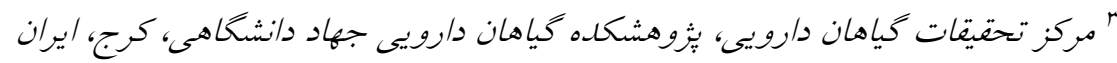

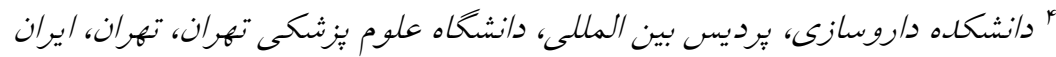

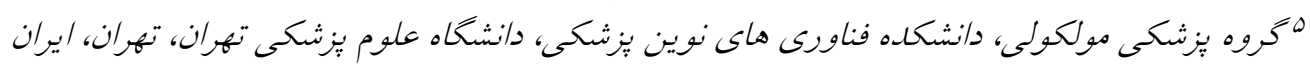

\begin{tabular}{|c|c|}
\hline جִكيده & اطلاعات مقاله \\
\hline مقدمه: ميوههاى جتريان به عنوان ادويه رايج براى ييشخيرى و درمان بسيارى از بيمارى هاى مزمن به كار مىروند. & 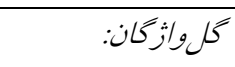 \\
\hline هدف: مطالعه حاضر به بررسى خواص بيولوزيكى ميوههاى مختلف از قبيلههاى گوناكون خانواده جِتريان مى يردازد & جتريان \\
\hline و با مقايسه آنها سعى دارد فراكشن (هاى) داراى خواص بالقوه شامل بيشخيرى از سرطان را براى مطالعات آينده & ميوهها \\
\hline بيابد. روش بررسى: ميوه كرفس، زيره كرمانى، جعفرى، انيسون، باديان رومى (زنيان)، كشنيز، رازيانه، شويد، كلير، & سميت سلولى \\
\hline آنقوزه، زيره سبز و هويج به وسيله متانول •^ درصد عصارهخيرى و سِس عصارهها به ترتيب با بتروليوم اتر، & قدرت احياكندكى \\
\hline كلروفرم و اتيل استات فراكشنه و باقيمانده فراكشن متانولى ناميده شد. ميزان سميت سلولى عصاره تام و فراكشنها & \\
\hline به وسيله تست BST و MTT در برابر سلولهاى سرطانى و نرمال بررسى كرديد، ميزان اثر آنتى اكسيدانى و فنول & \\
\hline تام نمونهها به ترتيب با تست FRAP و فولين سيو كالتو تعيين گرديد. نتايج: در تست BST، سميت عمومى & \\
\hline فراكشنهاى اتيل استات (ميانكين دادهها) بيش از ساير نمونهها بود. سمىترين فراكشنها در برابر سلولهاى & \\
\hline سرطانى HT-29، ADA-MB-231 و A549 از قبايل Ammineae بودند Peucedaneae و فراكشنهاى & \\
\hline حاوى مقادير بالاى تركيبات فنولى و با قدرت آنتىاكسيدانى متعلق به قبيله Ammineae بودند. نتيجه كيرى: & \\
\hline ميوههاى خانو اده جتر يان داراى اثرات قابل توجه بيولوزيكى مىباشند، به همين دليل جداسازى تركيبات فيتوشيميايى & \\
\hline از فراكشنهاى فعال با اثر سميت سلولى، در مطالعات آينده بيشنهاد مى كردد. & \\
\hline
\end{tabular}

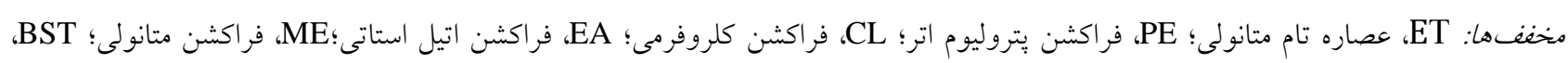

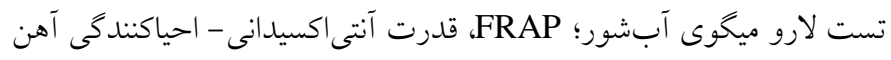

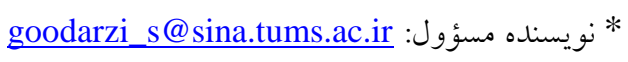

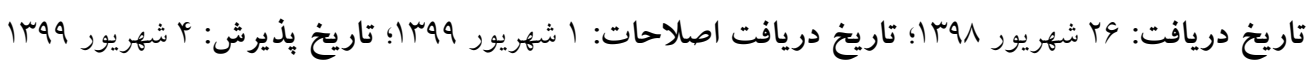
doi: $10.29252 / \mathrm{jmp} .19 .76 .46$

(c) 2020. Open access. This article is distributed under the terms of the Creative Commons Attribution-NonCommercial 4.0 International License (https://creativecommons.org/licenses/by-nc/4.0/) 